\title{
IMPROVING THE CROSSLINK DENSITY AND THE MECHANICAL PROPERTIES AFTER VULCANIZATION FOR AN IRON OXIDE LAYER (SCALE) AND SBR/RUBBER MASTERBATCH
}

\author{
IZBOLJŠANJE GOSTOTE PREČNEGA ZAMREŽENJA IN \\ MEHANSKIH LASTNOSTI Z VULKANIZACIJO IZDELANEGA \\ KOMPOZITA IZ STIREN-BUTADIENSKE GUME IN ŠKAJE
}

\author{
Şaban Bülbül \\ Necmettin Erbakan University, Faculty of Seydişehir Ahmet Cengiz Engineering, 42370 Konya, Turkey \\ Prejem rokopisa - received: 2019-06-14; sprejem za objavo - accepted for publication: 2019-08-18
}

doi:10.17222/mit.2019.129

\begin{abstract}
In this study iron oxide layers (IOLs) formed on the surfaces of ingots during a rolling process were supplemented into stiren-butadiene rubber (SBR) based on a referenced rubber-back composition of 5-10-15-20\%, and accordingly five different samples were prepared. After vulcanization, the hardness, density, abrasion loss, tensile strength, percentage elongation, tearing strength and crosslink densities were measured. In addition to that, the effects of the crosslink density on the mechanical properties are discussed. The properties of the generated new compounds are comparatively discussed, both with respect to themselves and with those of the referenced rubber. It was observed that the iron oxide layer significantly reduces the cost of compound, and increases the wearing resistance with the increasing of the crosslink density, and provides an advantage for the properties of hardness, tensile strength, tearing strength and percentage elongation. In order to explain the changes in the mechanical properties, the fracture surfaces were characterized by Scanning Electron Microscopy (SEM) and Energy-Dispersive Spectroscopy (EDS). When the SEM images are examined, it is seen that the filler dispersion in the rubber matrix is adversely affected by its increasing amount. The improved materials are discussed in terms of their usability in outsole applications.

Keywords: compound, mechanical properties, iron oxide layer, crosslink
\end{abstract}

V prispevku avtor predstavlja študijo priprave kompozitov na osnovi stiren-butadienske gume (SBR), kateri je bil kot ojačitvena faza dodan železov oksid (IOL), ki nastaja kot škaja na površini ingotov med postopkom vročega valjanja. Pripravili so pet različnih mešanic s $(5,10,15$ in 20$) \%$, IOL. Po vulkanizaciji so določili trdoto, odpornost proti abrazijski obrabi, gostoto, natezno trdnost, raztezek, strižno trdnost in gostoto prečnega zamreženja. Dodatno so analizirali vpliv gostote prečnega zamreženja na mehanske lastnosti. Lastnosti novih kompozitov so primerjali med seboj in z referenčno osnovo (čisto SBR, brez dodatka polnila). Ugotovili so, da IOL pomembno zmanjša ceno kompozita, izboljša odpornost proti obrabi s povečanjem gostote prečnega zamreženja, kakor tudi druge lastnosti, kot so: trdota, natezna in strižna trdnost ter raztezek. Da bi razložili spremembe mehanskih lastnosti izdelanih kompozitov, so okarakterizirali prelomne površine z vrstičnim elektronskim mikroskopom (SEM) in energijsko disperzijsko spektroskopijo (EDS). Na osnovi SEM posnetkov avtorji ugotavljajo, da porazdelitev polnila oz. njegova disperzija v matrici gume, učinkuje sorazmerno $\mathrm{z}$ naraščajočim deležem polnila. Avtorji $\mathrm{v}$ zaključku še ugotavljajo, kakšna je uporabnost teh kompozitov v čevljarstvu za izdelavo podplatov.

Ključne besede: spojina, mehanske lastnosti, plast železovega oksida, prečno zamreženje

\section{INTRODUCTION}

Rubber can be examined in two groups as natural rubber derived from the essence (latex) of the rubber tree (hevea brasiliensis), and synthetic rubber produced from petroleum. The areas of usage of rubber materials are increasing day by day. Especially in the automotive sector, it is widely used in medical applications, toys, shoe soles, oil and water pumps, energy transfer, buildings and highways. ${ }^{1}$ Although there are applications where the desired performance properties can be obtained by using a single rubber type; in the majority of applications, more than one rubber is blended so as to benefit from the properties of all the included rubbers, at

*Corresponding author's e-mail:

sabanbulbul42@hotmail.com (Şaban Bülbül) certain levels, and sometimes superior properties are obtained. The blending of rubbers is applied in some cases to lower the cost.

The strengths of rubbers are low when used as a reinforcing filler. They are often mixed with reinforcing fillers to prepare rubber with higher strength. This makes it important for both the careful selection of the filler used, and to carry out further works to improve the properties of the fillers. The most commonly used fillers in the production of rubber materials are fillers of carbon blacks and silicates. Moreover, it is also possible to use non-reinforcing fillers such as calcium carbonate, talk, barite, etc. for reducing the costs; there are also studies in which many herbal and mineral origin wastes are utilized as a filler. ${ }^{2-4}$ The varying price of carbon black, arising from the instability in oil prices, produced from unrenewable resources such as petroleum and natural 
gas, has recently enforced the industry to search for alternative filler materials. ${ }^{5}$

When the relevant studies in the literature are reviewed, it is seen that many filler materials such as rice husk, clay, wood ash, regenerated (recycled) rubber, blast furnace flue dust, mica powder, wollastonite etc. are used as an alternative to carbon black. ${ }^{6-8}$ In addition, it is known that these fillers and additives added to the rubber have a significant effect on the crosslink density after vulcanization. When the studies discussing the effects of fillers on the crosslink density are reviewed, a great number of alternative fillers are seen to be used. P. Pitchapa et al. added pineapple leaf fibers, together with carbon black, into a natural rubber (NR) matrix, and investigated the effects of crosslink density within the matrix included hybrid filler, on the mechanical properties, by changing the sulfur ratio by $2 \%$ to $4 \%$. They observed an increase in the tearing and tensile strengths of the material, with the increase in the amount of crosslink in the in which single filler had been used. But they stated that this increase was more evident in the case of hybrid filler use. Similarly, the percentage elongation of the improved material with the increase in the amount of crosslink. ${ }^{9}$ It was emphasized in a limited number of studies done regarding the effect of crosslink density on the mechanical properties that filler and additive materials also affect the density of the crosslink. ${ }^{10-12}$ Wong et observed an increase in the crosslink density when a certain amount of graphene oxide was added into a BR compound with a SBR matrix. They emphasized that the tensile strengths and percentage elongation of the with SBR matrix increased, depending on the increase in the crosslink density. As a consequence, it has been proven that graphene oxide can be used as an agent that can increase the crosslink efficiency when used as an additional filler in addition to the other fillers. ${ }^{13}$

The crosslink density for rubber is one of the most influential parameters on the physical, mechanical and dynamic properties. The hardness of the material increases with the increasing crosslink density, which also leads to an increase in the hardness. The elastic properties, and accordingly the permanent deformation gets better, with a high crosslink density. However, as well as crosslink density, the type of crosslink is also effective on mechanical properties, such as tensile strength, percentage elongation, tearing strength, and on aging strength. ${ }^{14}$ The effect of crosslink density on the material properties is an issue that needs to be evaluated from various aspects. Today, the utilization of wastes, not possible to be recycled with other methods, as a filler for appropriate matrices, especially for polymeric materials, for a sustainable economy and environment draws a great deal of interest. In this way, it may be possible to reduce the dependence on non-renewable raw materials. Besides, it is seen that many wastes have the potential to improve the properties of the polymeric matrix into which they have been added, in the event that an appropriate interface can be obtained. B. Karaağaç, ${ }^{15}$ in his study, used pistachio husk as an alternative filler material in a NR/SBR-based conveyor belt compound. The vulcanized characteristics, mechanical, thermal, morphological and abrasion characteristics of containing pistachio husk were investigated. Increasing the rate of addition of the pistachio husk into the rubber compound led the vulcanized degree to decrease, and the tensile strength to reduce. However, the abrasion resistance could be improved significantly with the inclusion of pistachio husk. It has been reported that the low price, environmentally friendly and high abrasion resistant could be produced if some losses in the tensile properties could be tolerated. Another study in which non-recyclable materials were used as fillers was conducted by R. L. Timings. ${ }^{16}$ New compound compositions were formed by adding paper, fabric pieces and wood dust in specific ratios into the rubber compound. It was reported that wood dust reduces the cost and the pieces of paper and cloth improved the electrical insulation. Finally, M. N. Ichazo et al. ${ }^{17}$ proved that permanent deformation and aging properties of natural rubber strongly depend on the particle sizes of the fillers added, and concluded that these properties were almost unaffected by the addition of wood dust with small particle size (less than 250-300 $\mu \mathrm{m})$. On the other hand, the addition of wood dust to rubber compound increased the tensile strength, and the reinforced with 300-425 $\mu \mathrm{m}$ wood dust yielded better results than the reference. Therefore, it has been concluded that wood dust from tropical trees such as "Puy" and "Algarrobo" can be used as a semi-strengthening filler.

The aim of this study was to investigate whether the oxide layer, which is produced as waste in rolling plants and not possible to be recycled with other methods, can be used as a filler, and whether the resulting compound compositions can be used for outsole applications. In this way it will be possible to prevent the environmental damage that may be caused by the disposal of the waste oxide layer directly into the nature, and shed light on new studies on the recyclability of wastes with a similar structure.

\section{EXPERIMENTAL PART}

\subsection{Materials}

The SBR 1502 / Rubber masterbatch used in this study was supplied from Defne Kauçuk Import and Export Co. Ltd., (Turkey), and rubber powders and calcite $\left(\mathrm{CaCO}_{3}\right)$ from Petkim Inc (Turkey). The oxide layer was supplied from a rolling plant, namely, Yolbulan Demir San. and Co. Ltd., (Turkey). Other additives used in the study were purchased from Bayer Kimya Co. Ltd., (Turkey). The densities of all fillers are given in Table 1.

The solvents used in the swelling test (acetone and chloroform) were supplied from Bereket Kimya Co. Ltd., Turkey. 
Table 1: Densities of compound components

\begin{tabular}{|l|c|}
\hline \multicolumn{1}{|c|}{ Components } & Density $\left(\mathrm{g} / \mathrm{cm}^{3}\right)$ \\
\hline SBR 1502 & 0.94 \\
\hline Rubber Masterbatch & 1.18 \\
\hline Rubber Powder & 1.17 \\
\hline Calcite $\left(\mathrm{CaCO}_{3}\right)$ & 2.71 \\
\hline Scale (Iron Oxide Layer) & 3.40 \\
\hline
\end{tabular}

\subsubsection{Rubber back (Masterbatch)}

It was extracted from non-vulcanized, regarded as non-standard by plants producing technical rubber compound, prepared by mixing filler, process oil and vulcanizing agents together with two or more rubbers. Rubber masterbatch used in this study contains $70 \%$ natural rubber, $20 \%$ SBR and $10 \%$ cis-butadiene rubber (CBR). Its specific weight is about $1.18 \mathrm{~g} / \mathrm{cm}^{3}$ and the tensile strength after being vulcanized is about 17-22 MPa, while the hardness is about 65 Shore A.

\subsubsection{Oxide layer}

The oxide layer is a metal oxide layer formed as a result of reacting of iron annealed up to $700{ }^{\circ} \mathrm{C}$, with oxidizing gases (such as sulfur and oxygen), while being rolled. The oxide layer contains $69.94 \% \mathrm{Fe}$ and $30.06 \%$ $\mathrm{O}_{2}$ when it is in the pure state. Rolling equipment oriented oil inclusions can occur during the rolling process. The oil content usually varies between 0.1 and $2.0 \%$, but sometimes this rate extends up to $10 \%$. The chemical analysis of the oxide layer used in the study is given in Table 2.

Table 2: Chemical analysis of the oxide layer used in the study

\begin{tabular}{|c|c|c|c|c|c|c|}
\hline Content & $\mathrm{Fe}_{2} \mathrm{O}_{3}$ & $\mathrm{TiO}_{2}$ & $\mathrm{SiO}_{2}$ & $\mathrm{CaCO}_{3}$ & $\mathrm{MgCO}_{3}$ & $\mathrm{Al}_{2} \mathrm{O}_{3}$ \\
\hline $\begin{array}{c}\text { Percentage } \\
\text { by weight }\end{array}$ & 94.52 & 0.23 & 1.74 & 0.96 & 1.05 & 0.40 \\
\hline
\end{tabular}

It was seen that approximately $3 \%$ of the oxide layer formed on the ingots were broken away from the surface. This broken oxide layers were collected and ground into the grain size of $20 \mu \mathrm{m}$, with the help of a Super Mixer brand SM 132 model grinder working at high speed $\left(11,000 \mathrm{~min}^{-1}\right)$.

\subsection{Methods}

\subsubsection{Preparation of rubber compound}

Rubber master batch, SBR and filler materials were mixed in a laboratory-type banbury device (Farrell brand) at $60 \mathrm{~min}^{-1}$ and $80{ }^{\circ} \mathrm{C}$ for $10 \mathrm{~min}$. The compound was mixed in a two-roll mill at a speed of $40 \mathrm{~min}^{-1}$ at $80{ }^{\circ} \mathrm{C}$ for $5 \mathrm{~min}$., after being conditioned for 24-hour incubation. The oxide layers in the amounts of $5 \%$, $10 \%, 15 \%$ and $20 \%$ by weight were added and mixing process continued for $5 \mathrm{~min}$. more. Finally, softeners, activators, accelerators and sulfur were added into the compound and mixed for $2 \mathrm{~min}$. and the process was finished after transforming the compound into sheet. The formulations of the compounds are given in Table 3 .

Table 3: Composition of rubber compounds

\begin{tabular}{|l|c|c|c|c|c|c|}
\hline \multirow{2}{*}{\multicolumn{1}{c|}{ Compounds }} & \multicolumn{5}{c|}{ Sample Codes } \\
\cline { 2 - 6 } & $\mathrm{G}$ & IOL1 & IOL2 & IOL3 & IOL4 \\
\cline { 2 - 6 } & \multicolumn{5}{|c|}{ Weight in phr. } \\
\hline SBR 1502 & 90 & 90 & 90 & 90 & 90 \\
\hline Masterbatch & 10 & 10 & 10 & 10 & 10 \\
\hline Rubber powder & 50 & 50 & 50 & 50 & 50 \\
\hline Calcite $\left(\mathrm{CaCO}_{3}\right)$ & 10 & 10 & 10 & 10 & 10 \\
\hline Sulfur & 3 & 3 & 3 & 3 & 3 \\
\hline MBT $^{\text {a }}$ & 0.5 & 0.5 & 0.5 & 0.5 & 0.5 \\
\hline CZ $^{\text {b }}$ & 1 & 1 & 1 & 1 & 1 \\
\hline DPG $^{\text {c }}$ & 1 & 1 & 1 & 1 & 1 \\
\hline Stearic acid & 4 & 4 & 4 & 4 & 4 \\
\hline Zinc oxide & 4 & 4 & 4 & 4 & 4 \\
\hline Scale (Iron oxide layer) & 0 & 5 & 10 & 15 & 20 \\
\hline
\end{tabular}

a2-Mercaptobenzothiazole, ${ }^{\mathrm{b}} \mathrm{N}-\mathrm{Cyclohexyl-2-benzothiazole} \mathrm{sulfo-}$ namide, ${ }^{\mathrm{c} D i p h e n y l ~ g u a n i d i n e}$

\subsubsection{Vucalization of rubber compounds}

The rubber compounds transformation into flat sheet were cut in small pieces, placed in a $(180 \times 180 \times 6) \mathrm{mm}$ mold that could be compressed by press (Hidrosan) device for $150{ }^{\circ} \mathrm{C}$ at $6 \mathrm{~min}$. under $16 \mathrm{MPa}$ pressure and the compounds were vulcanized under the same conditions. All these compounds used in experimental studies were prepared under same parameters.

\subsubsection{Characterization}

The samples were conditioned for $24 \mathrm{~h}$ at $25 \pm 2{ }^{\circ} \mathrm{C}$ in an environment containing $50 \%$ relative humidity before the test was performed. The tensile test was carried out in accordance with ISO 37 standard at a speed of $10 \mathrm{~mm} / \mathrm{s}$ through a Tinius brand H25KS model tensile testing device. The hardness of the material was measured in Shore A, in accordance with ISO 868, through a AffriCommerciale brand AFFRI 3001 model durometer. The tearing test was performed through the same tearing device, in accordance with ISO 34 standard. The density measurements were made pursuant to ISO 2781, in accordance with Archimedes principle, and pure water was used as the reference liquid. In the wearing tests, performed pursuant to ISO 4649 standard; the volume loss was measured, occured after a test sample under a $10 \mathrm{~N}$ perpendicular force, placed on a drum rotating at $84 \mathrm{~min}^{-1}$, covered a distance of $40 \mathrm{~m}$.

The crosslink densities of the rubbers were calculated using equilibrium volume swelling equation known as the Flory-Rehner equation. ${ }^{18}$ This method is based on the principle of swelling rubbers in a suitable solvent. It is known that the elastic recovery forces are inversely proportional to the length of the polymer chains between the cross-linking points. Therefore, the crosslink density was considered lower in samples that exhibited high swelling in the solvent. The test samples were kept waiting in a chlorofrom medium for $72 \mathrm{~h}$, and cross-link 
density, interrelated to swelling ratio in the solvent, was calculated using Flory-Rehner equation (Equation (1)):

$$
V_{\mathrm{e}}=\frac{-\left[\ln \left(1-V_{2}\right)+V_{2}+\chi V_{2}^{2}\right]}{V_{\mathrm{s}}\left[V_{2}^{1 / 3}-\frac{V_{2}}{2}\right]}
$$

In above equation,

$V_{\mathrm{e}}$ : Crosslink density $\left(\mathrm{mol} / \mathrm{cm}^{3}\right)$

$V_{2}$ : Volume fraction of swollen sample

$V_{\mathrm{s}}$ : Molar volume of solvent $\left(\mathrm{cm}^{3} / \mathrm{mol}\right)$

$\chi$ : Polymer - solvent interaction parameter

The morphologies of the fracture surfaces of the samples after the wearing test were reviewed using a Zeiss Ultra/Plus scanning electron microscope (SEM). The fracture surfaces of the samples were coated with 5 -nm-thick pure gold to increase its conductivity. ${ }^{19}$ The operating voltage of the microscope during the review of microstructure images was selected as $30 \mathrm{kV}$. The Energy-Dispersive Spectroscopy (EDS) analysis method was used to distinguish the components in the sample.

\section{RESULTS AND DISCUSSION}

\subsection{Crosslink density}

The crosslink densities of SBR/Rubber masterbatch are given in Figure 1, interrelatedly to the amount of oxide layer contained. It was observed that the crosslink density increased systematically with the increasing IOL. The highest crosslink density was measured in the IOL4 compound $\left(62.4947 \times 10^{6} \mathrm{~mol} / \mathrm{cm}^{3}\right)$. The crosslink density of the $\mathrm{G}$ compound, taken as a reference and not included oxide layer was measured $42.1338 \times 10^{6} \mathrm{~mol} / \mathrm{cm}^{3}$. Accordingly, it was seen that the crosslink density of the reference compound increased by about $48 \%$, with the addition of the oxide layer by $20 \%$. This increase is thought to be caused by two reasons. The first of these is the increase in the heat capacity of the compound, with the metal oxide added to the matrix, and the post-cure event that takes place due to more slowly decreasing of heat during the rest period.

The second one is the activities of metal oxides for moving their accelerator radicals to rubber main chains. Although the main activator used to exhibit this activity

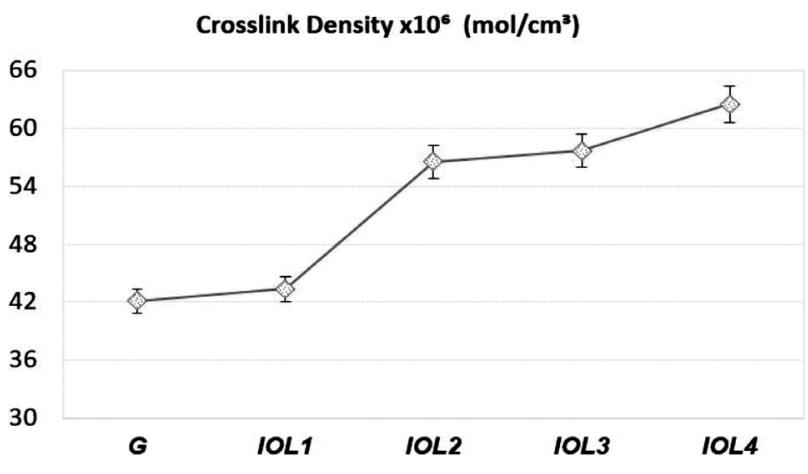

Figure 1: Crosslink density of compounds is zinc oxide, it is well known that all metal oxides perform similar tasks to zinc oxide. ${ }^{20,21}$ However, it is obvious that far more detailed chemical analyzes are required to clarify the activating effect of the oxide layer.

\subsection{Physical-mechanical properties}

The mechanical properties of SBR/Rubber masterbatch depend on many factors, such as chemical structure of rubber matrix, type and rate of fillers, amount and type of crosslinkers, degree of crosslinking, decomposition of crosslinkers and conditions of vulcanization. In this study the mechanical properties, in the presence of IOL, were evaluated by interrelating with the crosslink density.

The tension-deformation graph, for all, is given in Figure 2a. As well as tensile strength values are approximate to the referenced vulcanizate; an explicit increase was observed in the percantage elongation values. The high percentage elongation behavior for similar tension levels points out decreasing tension modulus levels in containing IOL. However, the crosslink density values, increasing in paralel with the amount of IOL, would require an increase in the tension modulus in the absence of another physical effect, which suggests that the increase in the percantage elongation values, in the presence of IOL, is due to the physical interactions between the chains rather than the crosslink structure of the material. It is also emphasized in the literature that with
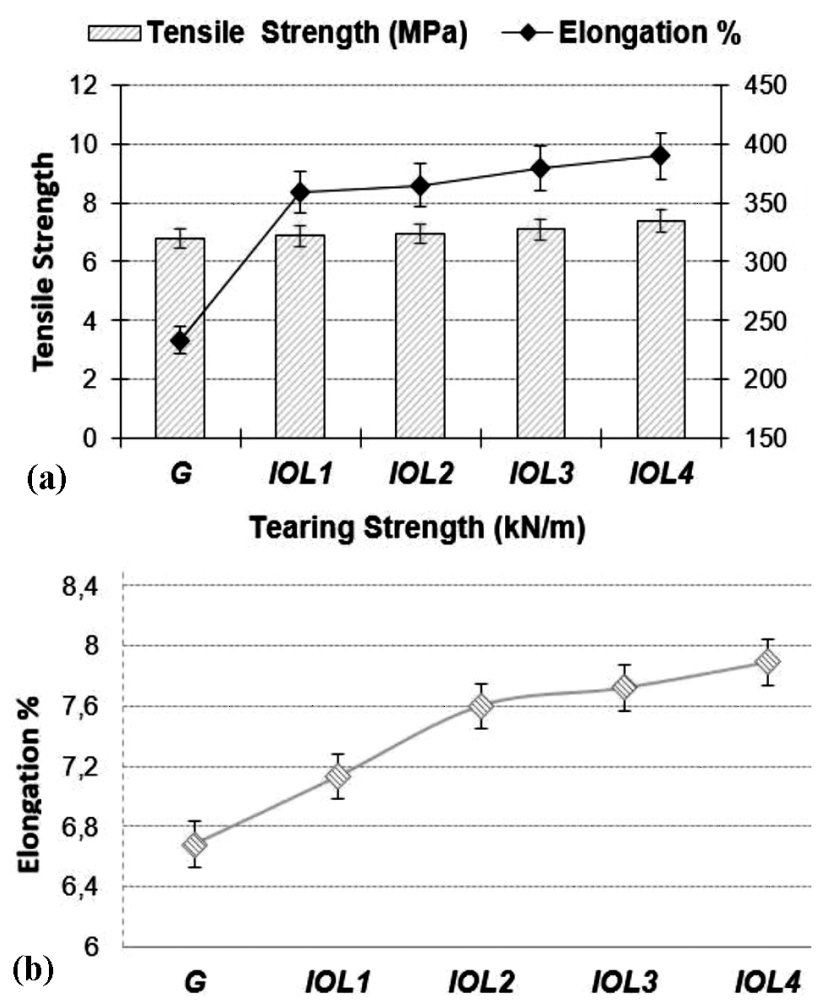

Figure 2: IOL amount dependent variation of mechanical properties of compounds: a) tensile strength and percantage elongation, b) tearing strength 
a high crosslink density there is a greater elongation in the presence of the additional physical interactions (such as van der Waals forces). ${ }^{22}$

It is seen in Figure 2 that the highest tensile strength was obtained for IOL4 coded vulcanizate, suplemented with IOL by $20 \%(7.47 \mathrm{MPa})$. The minimum tensile strength for rubber soles (outsole), according to relevant standards, is $5.8 \mathrm{MPa},{ }^{23,24}$ which can suggest that outsoles is a potential application area for economical and environmentally friendly rubber materials that can be produced by the addition of an oxide layer. When the test results of the percentage elongation values of compound $\mathrm{G}$ and IOL supplemented compounts were reviewed, it was seen that while the percentage elongation of compound G was $233 \%$, that of IOL supplemented varied between 359 and 390. It can be said that as well as the increase in the unit elongation amount caused a decrease in the tension module of, with increasing IOL addition, it also improved the elasticity property of the material. ${ }^{25}$

The potential physical interactions in fillers, added to the rubber compound, is high if the diffusion is sufficient, which strengthens the rubber-filler interface. It is known that the tensile strength, percantage elongation, and tearing strength properties of the material obtained from this compound are improved with the contribution of a high crosslink density. ${ }^{26-28}$ In this study, it is thought that the mechanical properties are improved with the development of rubber-filler interface in increasing oxide layer ratios. Figure $\mathbf{2 b}$ shows that while the tearing strength of the G-coded referenced compound was $6.68 \mathrm{kN} / \mathrm{m}$, that of the IOL4-coded compound, prepared with oxide layer addition by $20 \%$, ratio up $7.89 \mathrm{kN} / \mathrm{m}$. Considering that the tearing strength limit for outsole materials, which are deemed as potential usage area, is 6 $\mathrm{kN} / \mathrm{m}$ according to ISO 5676 standard, it is logical to think that the oxide-layer-reinforced material can be used safely for this purpose. The oxide layer chemically contains a small amount of $\mathrm{SiO}_{2}$ (Silica), $\mathrm{CaCO}_{3}$ (Calcite), $\mathrm{Al}_{2} \mathrm{O}_{3}$ and highly stable $\mathrm{Fe}_{2} \mathrm{O}_{3}$ (Table 2). In the literature there are studies reporting that the physical and mechanical properties can be improved with the addition of a major part of these components..$^{29-31}$

The target density in the elastomeric materials varies depending on the environment and conditions in which the material will be used. The desired maximum density value of the soles, according to ISO 4649 standard, is $1.5 \mathrm{~g} / \mathrm{cm}^{3}$. Figure 3a shows that samples' densities are below the upper limit value specified in the standard. As the supplement ratio of IOL filler increased, the densities of the material expectedly increased as well. The reason for this increase is that the density of the oxide layer, added to SBR/Rubber masterbatch compound, is higher than that of other fillers and the rubber matrix used in the study (Table 1). Other parameters discussed for the SBR/Rubber masterbatch compound after the addition of oxide layer are the hardness and the abrasion loss. The

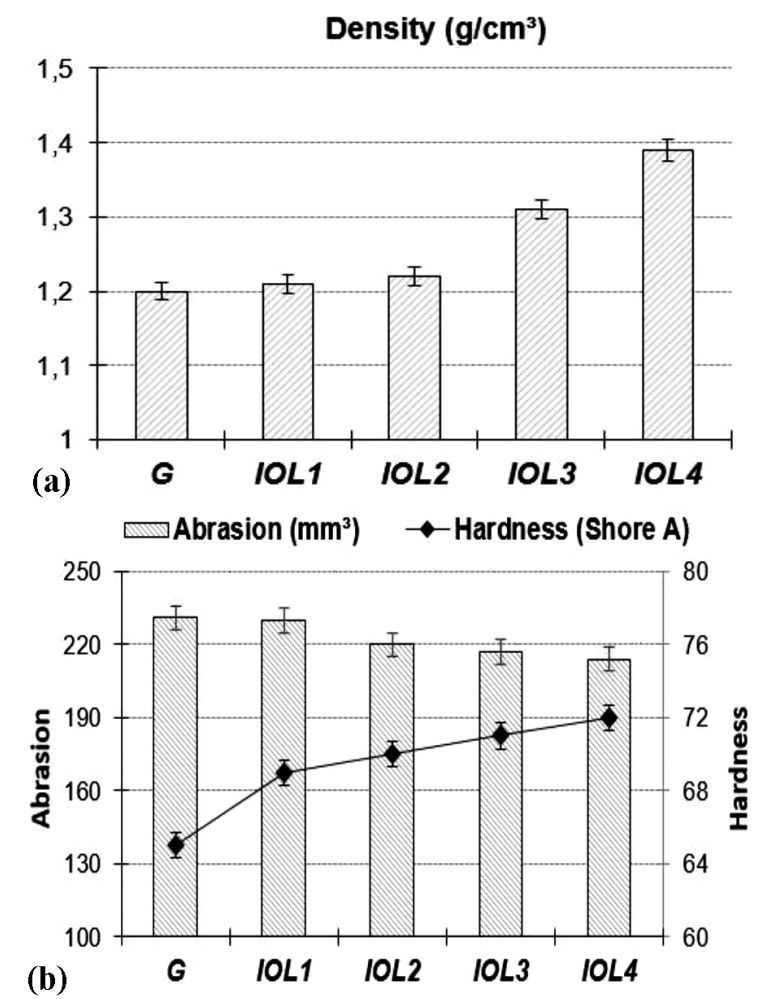

Figure 3: Change of physical properties of compounds depending on increasing IOL ratio: a) density, b) hardness and abrasion loss

change of both parameters according to the amount of IOL is given in Figure 3b.

As can be seen from the figure, as the amount of IOL added to the SBR/Rubber masterbatch compound increases, the hardness of the compound also increases after the vulcanization. In the hardness measurements made in accordance with the ISO 868 standard; as well as the hardness of G-coded compound was measured to be 65 Shore A; the hardness values in parallel with IOL amount, were seen to increase between $6.1 \%$ and $10.7 \%$ as compared to reference. Regarding the samples with IOL filler; the lowest hardness value was measured as 69 Shore A at IOL1, the highest hardness value was measured as 72 Shore A at IOL4. It is known that metal oxides and carbide oxides are far harder than polymeric materials in general. $\mathrm{Fe}_{2} \mathrm{O}_{3}$ constitutes an important fraction of the IOL filler used in the study. Another reason for the increase in the hardness is thought to be an increase in the crosslink densities of the material.

A standard rubber stated that in ISO 4649 is required to determine the abrasion resistance index (ARI) of the vulcanisates for comparison. According to the standard, the maximum acceptable abrasion loss is $250 \mathrm{~mm}^{3}$. Figure 3b shows the abrasion loss of the vulcanisates were relatively similar. It is seen that the maximum abrasion loss occurred in the reference $G$ sample. The minimum abrasion loss was measured in the IOL4 sample containing the oxide layer in the ratio of $20 \%$ $\left(214 \mathrm{~mm}^{3}\right)$. The high abrasion resistance of the metal 
oxides contained in the oxide layer improved the total abrasion resistance of the rubber material in proportion to the fraction in which it is contained. This finding shows parallelism with the results of the studies in the literature. ${ }^{32-34}$ It was seen that all the containing oxide layer could ensure the abrasion resistance standard required for the outsole.

\subsection{Morphological analysis}

The SEM images of the fracture surfaces of all after fracture tensile tests are given in Figure 4. When the fracture surfaces were examined, it was seen that with the increase of the amount of oxide layer, the oxide layer on the fracture surface became clearer, the grain sizes changed and the filler diffusion on the interface was expectedly disrupted. It was observed that the distance between the filler agglomerates decreased, even they formed an aggregate imagine by gathering. The fracture largely occurred throughout the oxide layer agglomerates, which is such as to verify the parallel relationship between the increase in the oxide layer amount, and fracture. Another factor for the improvement of the fracture resistance is considered to be the increasing crosslink density at increasing oxide-layer rates. In the G-coded compound (Figure 4a); instead of deep pit zones formed during the exit of the fracture filler, the fracture zones of the rubber, offering a wavy imagine draw the attention, which suggests that a different facture mechanism is being followed.

EDS analysis was performed to determine the fracture surface morphologies after tensile test applied to the produced material by adding the iron oxide layer in different ratios. The EDS analysis was realized especially in the areas exhibiting elevations where a regional difference was observed for the fracture surface morphologies of the tensile test samples (Figure 5).

This was necessary in order to determine the dispersion of the iron oxide layer in the dispersed material. Even though the EDS analyses reveals elemental results, it can also give important results about the differentiation of the dispersion as well as about the fracture surface forms based on this differentiation. In this study, the Fe elemental distribution was emphasized even though the EDS analyses were carried out on alloy elements in the chemical composition of the dopants and fillers added into rubber compound with SBR 1502 rubber matrix. With increasing amount of filler added into the material, the amount of $\mathrm{Fe}$ on fracture surfaces was observed to increase. Although there was no iron oxide layer within the $\mathrm{G}$ compound, it was observed according to the results of the chemical analysis that it contained $\mathrm{Fe}$ in the amount of $0.7 \%$ and was homogenously distributed. It was thought that this was associated with the rubber powder used in the study (tire recycling).

When all the EDS results were examined, it was found that the amount of $\mathrm{Fe}$ in the microstructure changed depending on increasing amount of iron oxide layer, which thus made a fundamental difference and $\mathrm{Fe}$ distribution played a determining role in the fracture results.

\subsection{Cost analysis}

The highest price is seen to belong to the reference compound $(\mathrm{G})$ in the unit price analysis. As the ratio of
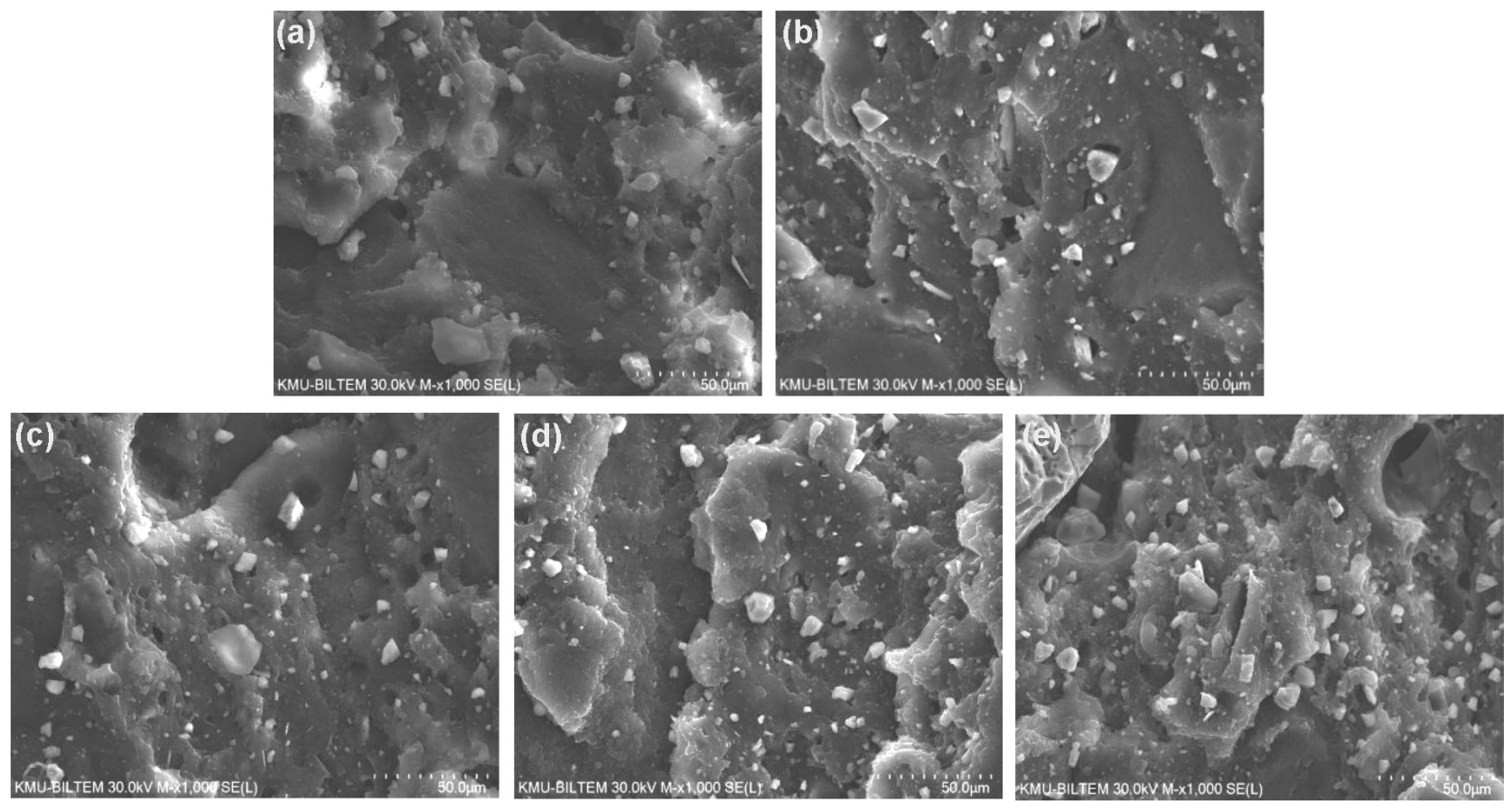

Figure 4: SEM images of: a) G, b) IOL1, c) IOL2, d) IOL3 and e) IOL4 compounds 


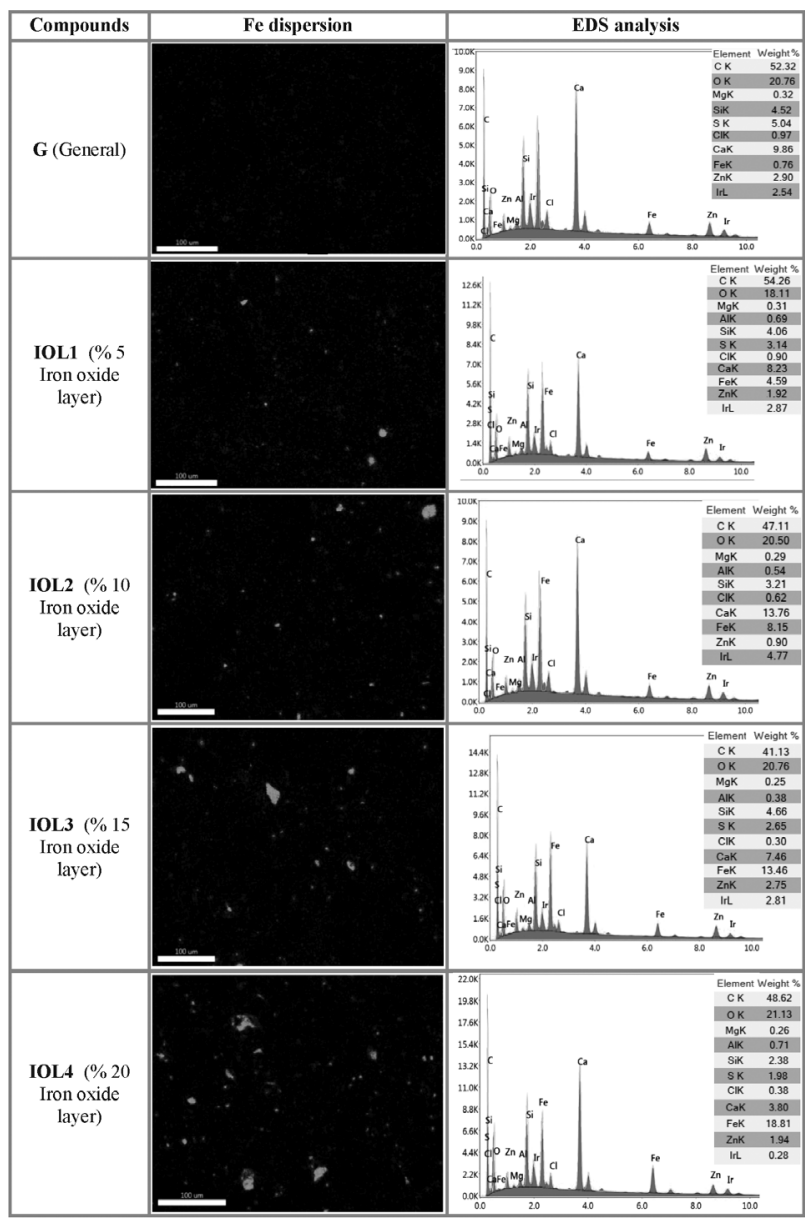

Figure 5: EDS analysis of the fracture surfaces and the Fe dispersion

the IOL filler added to the G compound increased, a proportional decrease was observed in the total compound cost (Figure 6). The raw material cost of IOL4 compound, into which oxide layer in the amount of $20 \%$ was added, is lower by $13.16 \%$ than the $\mathrm{G}$ compound. This decrease ranged between 2.6 and $7.91 \%$ for the other material.

The lack of any commercial value of oxide layer allows the cost of raw materials to be reduced in the case of being used as a filler in materials like rubber, which allows mixing in the solid phase. The transportation cost was ignored in the cost calculation. Besides, the avail-

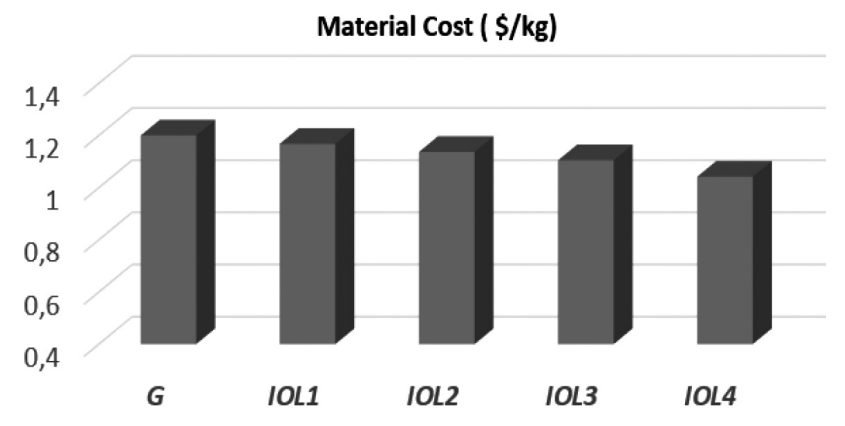

Figure 6: Cost analysis of compounds ability of harmlessly disposal of oxide layer in this way, released as a waste in rolling plants, attaches importance for sustainable environmental policies. The fact that the oxide layer can be used in the SBR/Rubber masterbatch compound thus decreasing the cost of compound, and improve the percentage elongation and abrasion resistance, which makes the use of oxide layer attractive, and significantly increases the value of the waste. The SBR/Rubber masterbatch containing oxide layer was found to have a high usage potential in outsole production. Accordingly, it is thought that with the use of oxide layer, especially small-scale producers can become competitive in terms of price and quality.

\section{CONCLUSIONS}

In this study the effect of oxide layer support on the physical, mechanical and morphological properties of SBR/Rubber masterbatch matrix rubber was reviewed, and the findings were attempted to be interrelated with the crosslink densities of the material. The compound compositions studied were discussed for the production of outsoles as a potential usage area. With the addition of oxide layer to rubber, it was seen that the density and hardness of the material increased, the abrasion resistance was improved significantly and high percentage elongation values were obtained without any loss in the tensile strength. All of the changes in physical and mechanical properties occurred in parallel with the content of oxide layer in the compound. The improvement in the mechanical properties was attributed to the increased crosslink density, in the presence of oxide layer, and also to the physical interactions of the oxide layer in the structure of the metal oxide with rubber chains. It was concluded that the SBR/Back Rubber prepared with the addition of oxide layer up to $20 \%$ satisfies the properties specified in the production of the outsole, defined in the ISO 4649 standard, and they can be used in the production of competitive sole as they are economic and environment friendly.

\section{Acknowledgements}

I would like to express my gratitude towards my invaluable teacher Assoc. Prof. Dr. Miss Assoc. Prof. Dr. Bagdagül KARAAGAÇ, from Kocaeli University, Faculty of Engineering, Department of Chemical Engineering, is thanked for helping me in this study, and for sharing her knowledge and experiences with me.

\section{REFERENCES}

${ }^{1}$ S. Cavdar, T. Ozdemir, A. Usanmaz, Comparative study on mechanical, thermal, viscoelastic and rheological properties of vulcanized EPDM rubber, Plastics Rubber and Composites, 39 (2010) 6, 277-282, doi:10.1179/174328910X12647080902970.

${ }^{2}$ N. Akcakale, Effects of carburized rice husk powders on physical properties of elastomer based materials, KGK-Kautschuk Gummi Kunststoffe, 70 (2017) (10/17), 49-54 


\section{Ş. BÜLBÜL: IMPROVING THE CROSSLINK DENSITY AND THE MECHANICAL PROPERTIES AFTER VULCANIZATION ...}

${ }^{3}$ Ş. Bülbül, M. Yaşar, N. Akçakale, Effect of changing of filling materials in NR-SBR type elastomer based rubber materials on mechanical properties, Polymer (Korea), 38( (2014) 5, 664-670, doi:10.7317/pk.2014.38.5.664

${ }^{4}$ N. Akcakale, Ş. Bülbül, The effect of mica powder and wollastonite fillings on the mechanical properties of NR/SBR type elastomer, Journal of Rubber Research. 20 (2017) 3 157-167, doi:10.1007/ BF03449149

${ }^{5}$ C. R. G Furtado, J. L. Leblanc, R. C. R. Nunes, Mica as additional filler in SBR-silica, Eur. Polymer J. 36 (2000), 1717-1723, doi:10.1016/S0014-3057(99)00215-3

${ }^{6}$ Ş. Bülbül, The effect of various inorganic and organic fillers on the mechanical properties of NR-SBR type elastomer materials [dissertation], Karabük (TR), Karabuk University, 2014

${ }^{7} \mathrm{~N}$. Akçakale, Investigation of the effect of some additives on the mechanical properties of NR-SBR elastomer based sole materials, Sakarya (TR), Sakarya University, 2008

${ }^{8}$ S. G. Hedayatollah, J. A. Azam, Nanocomposites based on natural rubber, organoclay and nano-calcium carbonate: study on the structure, cure behavior, static and dynamic-mechanical properties, Applied Clay Science, 119 (2016), 348-357, doi:10.1016/j.clay. 2015.11.001

${ }^{9}$ P. Pitchapa, T. Sombat, A. Taweechai, Manipulation of mechanical properties of short pineapple leaf fiber reinforced natural rubber composites through variations in cross-link density and carbon black loading, Polymer Testing, 54 (2016), 84-89, doi:10.1016/ j.polymertesting.2016.07.002

${ }^{10}$ E. F. Devlin, The effect of cure variables on cis/trans isomerization in carbon-black-reinforced Cis-1,4-Polybutadiene, Rubber Chemistry and Technology, 59 (1986) 4, 666-670, doi:10.5254/1.3538227

${ }^{11}$ S. S. Choi, K. J. Hwang, B. T. Kim, Influence of bound polymer on cure characteristics of natural rubber reinforced with different types of carbon blacks, J. Appl. Polym. Sci., 98 (2005) 5, 2282-2289, doi:10.1002/app.22287

${ }^{12}$ S. S. Choi, Effect of bound rubber on characteristics of highly filled styrene-butadiene rubber with different types of carbon black, J. Appl. Polym. Sci., 93 (2004) 3, 1001-1006, doi:10.1002/app.20567

${ }^{13}$ X. Wang, L. Hengyi, H. Guangsu, C.L. Heng, W. Jinrong, Graphene oxide induced crosslinking and reinforcement of elastomers, Composites Science and Technology, 144 (2017), 223-229, doi:10.1016/j.compscitech.2017.03.006

${ }^{14}$ N. J. Morrison, M. Porter, Temperature effects on the stability of intermediates and crosslinks in sulfur vulcanization, Rubber Chemistry and Technology, 57 (1984) 1, 63-85, doi:10.5254/ 1.3536002

${ }^{15}$ B. Karaağaç, Use of ground pistachio shell as alternative filler in natural rubber/styrene-butadiene rubber-based rubber. Polymer Composites, 35 (2014) 2, 245-252, doi:10.1002/pc.22656

${ }^{16}$ R. L. Timings, Materials Technology, Level 3 1, Materials Science, Longman House Burnt mill, Hartow Essex, CM202ZJ, England, 1985

${ }^{17}$ M. N. Ichazo, M. Hermandez, C. Albano, J. Gonzales, Natural rubber filled with wood floor; influence of particle size, Proceedings of the 8th Polymers of Advanced Technologies International Symposium, 2005 Sep 13-16, Budapest, Hungary, 2005

${ }^{18} \mathrm{~S}$. G. Croll, Application of the Flory-Rehner equation and the griffith fracture criterion to paint stripping, Journal of Coating Technology Research, 7 (2010) 1, 49-55, doi:10.1007/s11998-0099166-4

${ }^{19}$ S. L. Flegler, J. W. Heckman, K. L. Klomparens, Scanning and transmission electron microscopy,England, Oxford University Press, 1993
${ }^{20}$ N. M. Ahmed, D. E. El-Nashar, The effect of zinc oxide-phosphate core-shell pigments on the properties of blend rubber composites, Materials and Design, 44 (2013), 1-11, doi:10.1016/j.matdes. 2012.07.016

${ }^{21}$ K. Pal, S. K. Pal, C. K. Das, J. K. Kim, Effect of fillers on morphological and wear characteristics of NR/HSR blends with E-glass fiber, Materials and Design, 35 (2012), 863-872, doi:10.1016/ j.matdes.2011.07.074

${ }^{22}$ F. Dong, P. Zhao, R. Dou, S. Feng, Amine-functionalized POSS as cross-linkers of polysiloxane containing $\gamma$-chloropropyl groups for preparing heat-curable silicone rubber, Materials Chemistry and Physics, 208 (2018), 19-27, doi:10.1016/j.matchemphys.2018. 01.024

${ }^{23}$ Ş. Bülbül, N. Akçakale, The production and mechanical properties of carburized corn cob ash added rubber compounds, KGK Kautschuk Gummi Kunststoffe, 72 (2019) 4/19, 30-35

${ }^{24}$ Ş. Bülbül, N. Akçakale, M. Yaşar, H. Gökmeşe, The effect of wood ash on the mechanical properties of rubber compounds, Materials and technology 53 (2019) 3, 333-339, doi:10.17222/mit.2018.126.

${ }^{25}$ V. Rao, J. Johns, Mechanical properties of thermoplastic elastomeric blends of chitosan and natural rubber latex, J. Appl. Polym. Sci. 107(4) (2008), 2217-2223, doi:10.1002/app.27265

${ }^{26}$ D. E. El-Nashar, N. M. Ahmed, A. A. Yehia, The role of ion-exchange bentonites in changing the properties of styrene-butadiene rubber composites, Materials and Design, 34 (2012), 137-142, doi:10.1016/j.matdes.2011.07.072

${ }^{27}$ A. Khalil, S. N. Shaikh, Z. R. Nudrat, H. Farzana, The Effect of silica on the properties of marble sludge filled hybrid natural rubber composites, Journal of King Saud University - Science, 25 (2013), 331-339, doi:10.1016/j.jksus.2013.02.004

${ }^{28}$ A. Khalil, S. N. Shaikh, Z. R. Nudrat, Characteristics of natural rubber hybrid composites based on marble sludge/ carbon black and marble sludge/rice husk derived silica, Journal of Industrial and Engineering Chemistry, 19 (2013), 1169-1176, doi:10.1016/j.jiec. 2012.12.014

${ }^{29}$ M. J. Wang, Effect of polymer-filler and filler-filler interactions on dynamic properties of filled vulcanizates, Rubber Chemistry and Technology, 71 (1998), 520-589, doi:10.5254/1.3538492

${ }^{30}$ L. S. Laurence, B. Yves, F. Lionel, L. Dominique, Dynamic mechanical properties of precipitated silica filled rubber: influence of morphology and coupling agent. Rubber Chemistry and Technology,76 (2003), 145-159, doi:10.5254/1.3547730

${ }^{31}$ T. Pojanavaraphan, R. Magaraphan, Fabrication and characterization of new semiconducting nanomaterials composed of natural layered silicates $\left(\mathrm{Na}^{+}-\mathrm{MMT}\right)$, natural rubber $(\mathrm{NR})$, and polypyrrole (PPy), Polymer, 51 (2010), 1111-1123, doi:10.1016/j.polymer.2009.07.003

${ }^{32}$ V. Vijayabaskar, V. K. Tikku, A. K. Bhowmick, Electron beam modification and crosslinking: influence of nitrile and carboxyl contents and level of unsaturation on structure and properties of nitrile rubber, Radiat. Phys. Chem., 75 (2006) 7, 779-792, doi:10.1016/ j.radphyschem.2005.12.030

${ }^{33}$ Q. Wang, F. Wang, K. Cheng, Effect of crosslink density on some properties of electron beam-irradiated styrene-butadiene rubber, Radiat. Phys. Chem., 78 (2009) 11, 1001-1005, doi:10.1016/ j.radphyschem.2009.06.001

${ }^{34}$ J. Kruzelak, R. Sykora, I. Hudec, B. Slovakia, Sulfur and peroxide curing of Rubber based on NR and NBR. Part II: Thermo-oxidative Ageing, KGK-Kautschuk Gummi Kunststoffe, 70 (3/17) (2017), $41-47$ 